\title{
Icy mountains in a warming world: Revisiting science from the end of the 1990s in the early 2020s
}

\author{
This article belongs to Ambio's 50th Anniversary Collection. Theme: Climate change \\ impacts
}

\author{
Wilfried Haeberli, Martin Beniston
}

Temperatures had been rising, and glaciers had been shrinking worldwide for more than a century. Since the 1970s, however, it had become clear that human-induced effects from increasing atmospheric greenhouse-gas concentrations have the potential of leading this development far beyond past natural variability ranges. The consequences would be irreversible for generations to come. The inspiration for the paper published in Ambio 1998 emerged in part from a special effort undertaken by the Royal Swedish Academy of Sciences related to a global overview on mountain environments and processes. It also came from the Special Report of the Intergovernmental Panel on Climate Change on "Regional Impacts of Climate Change" (IPCC 1997) where the elements pertaining to the mountain cryosphere in different parts of the world were included. Our paper in Ambio (Haeberli and Beniston 1998) attempted to promote an integrative and future-oriented approach concerning climate and icy mountains. It increased the attention to cryosphere processes in mountain regions such as Switzerland as one of the most tangible signs of, but also severe impact from, global warming. We were both newly appointed professors at Swiss universities, fascinated by our research field but at the same time deeply concerned about what was going on.

More than two decades since the paper was published the primary statements are still very much valid today. This documents how robust our knowledge and understanding about climate change and the fate of icy mountains have remained over the years. In the meantime, however, a striking acceleration of change has taken place, scientific knowledge has expanded tremendously, and new fields of research have started to emerge.

One key development in the intervening period has been the accelerating pace of change in global and regional temperatures. Based on data from NOAA and the European
Climate Assessment \& Dataset (ECA\&D), we see that in the 1990s, the decadal-scale global average temperature anomaly was less than $+0.5^{\circ} \mathrm{C}$ (based on the 1961-1990 reference period), while in the past decade, the anomaly has risen to almost $+0.9^{\circ} \mathrm{C}$. The rate of change has been multiplied by a factor of almost 4 in certain parts of the world; indeed, it took 90 years to reach a cumulative global warming of $+0.8^{\circ} \mathrm{C}$ in the 1990 s, but just 20 years since the turn of the twenty-first century to add an extra $0.8^{\circ} \mathrm{C}$. The figures for European summer maximum temperature (Tmax) change-the June-July-August Tmax being a highly relevant metric for summer glacier melt-are of the same order: the decadal-scale anomaly in the 1990s was $+0.5{ }^{\circ} \mathrm{C}$ and in the past decade has risen to $+1.36^{\circ} \mathrm{C}$, i.e., almost an extra degree in just 20 years. The 10 warmest years since the mid-nineteenth century, at the global and regional scales, have all taken place since the year 2000 and in Europe, eight of these record years have taken place since 2010. Not only have average temperatures evolved in a highly unfavorable manner for glacier mass balance but also extreme temperatures have substantially increased. Indeed since the year 2000 Europe has experienced a number of damaging heatwaves, in particular 2003, 2010, 2015, 2017, and 2019. In the summer of 2019, many records of TMax were exceeded in several parts of Europe, for example, reaching over $40{ }^{\circ} \mathrm{C}$ for the first time ever in countries like Belgium, the Netherlands, and Germany, and an unprecedented $42{ }^{\circ} \mathrm{C}$ in the Provence Alps of southern France in towns like Sisteron and Digne.

Switzerland has been no exception to this trend, and indeed, climate data show that the rate of warming in Switzerland has been 2-3 times greater than the global temperature change over the past 100 years (e.g., Beniston et al. 2016), which has inevitably deployed dramatic impacts on Alpine snow and ice. Records of the 
MeteoSwiss weather station data of Sion, in the Canton of Valais in the heart of the Alps (SW Switzerland), show that the number of hot days (i.e., exceeding $30^{\circ} \mathrm{C}$ ) has increased from an average of nine days per summer in the 1980s to more than 31 days in the last decade, and even over 40 days in 2015, 2017, and 2018. For very hot days, beyond $35^{\circ} \mathrm{C}$, these were unrecorded prior to the 2003 heat wave, which experienced eight days beyond this threshold and has since been equaled in 2015 and 2019. Beniston (2015) explored the changes in the relative frequency of hot and cold record temperature and showed that for the Alpine region, in the last decade, record high temperatures outnumber record cold days by a factor of 4-6, compared to a rather equal ratio of record highs to record lows in the 1980s. This ratio is seen to increase poleward in the last decade and exceeds 20:1 in Svalbard, for example, highlighting the rapid climate dynamics not only at high elevation but also at high latitudes. In addition, not only have the frequency and intensity of heat waves but also hot days increased rapidly since the turn of the century, the period during which extreme temperatures can be expected has changed from mid-June through end-August in the 1990s to early May through mid-September in the last decade, i.e., almost an extra month during which hot days can occur. These changes in extreme temperatures contribute greatly to accelerated ice-melt, since winter snow melts earlier and exposes bare ice for a longer period, enhancing the vulnerability of glaciers to high temperatures.

While the climate conditions outlined above were anticipated in the 1998 paper, the IPCC projections at the time were calling for such climates towards the middle and the second half of the twenty-first century, rather than as early as the past 5-10 years.

The 1998 paper recognized that "highest priority should be given to appropriate monitoring programs." Long-term monitoring of glaciers and permafrost indeed soon became pioneer projects for terrestrial components within the Global Climate Observing System (GCOS) in support of the United Nations Framework Convention on Climate Change (UNFCCC). While worldwide monitoring of mountain glaciers had a long tradition since the end of the nineteenth century, special efforts were undertaken concerning the much more difficult challenges of documenting changes in mountain permafrost. The results obtained leave no doubt that changes in the mountain cryosphere are becoming increasingly dramatic (Hock et al. 2019). The total glacier volume in the Alps decreased from some 120 $\mathrm{km}^{3}$ at the time of our Ambio publication to about $80-90$ $\mathrm{km}^{3}$ in 2020. This rapid, heavy loss reflects the historically unprecedented global glacier decline in the early twentyfirst century (Zemp et al. 2015). The present average yearly ice-volume loss of about $2 \mathrm{~km}^{3}$ clearly confirms the statement formulated already in 1998 that “ ... the Alps would lose major parts of their glacier cover within decades." As larger glaciers adjust slowly and with considerable delay to climate change, much of future ice loss is most probably irreversible already today. The time has, therefore, come to look beyond glaciers (Haeberli et al. 2019). Anticipating, modeling, and managing de-glaciated new cold-mountain landscapes with their interconnected geo- and ecosystems in growing imbalance now constitute an important emerging research field (Drenkhan et al. 2019). The formation of numerous new lakes at the immediate foot of steep deep-frozen peaks thereby plays an important role. Permafrost in such frozen mountains has already warmed up to several tens of meters below the surface (Harris et al. 2009) and will continue to degrade slowly but irreversibly for many generations to come. Due to the related changes in mechanical strength and hydraulic permeability, the stability of frozen mountain slopes will continue to decrease when most glaciers may already have long disappeared. The probability of occurrence related to a catastrophic flood triggered by a landslide from destabilizing icy mountains into a new lake at their foot cannot be defined precisely. It is, however, safe to state that this probability is now systematically increasing (Haeberli et al 2017). Besides increasing risks, new lakes also offer opportunities for tourism, hydropower, and water supply. Not only conflicting interests but also potential synergies must be considered as part of concrete, participative planning.

Declining snow and ice in mountain regions strongly affect hydrological regimes and water supply, especially in terms of seasonality and also quality. The melting of winter snow and glacier ice in summer provides a valuable buffer of additional water during the warm seasons, when water needs for agriculture but also evaporation losses are highest. Continued reduction in snow and glacier area will eventually result in an overall reduction of meltwater contribution to river flows from late spring to early autumn. Decreasing water supply during summer is already observed in various mountain regions and affects both, upland and densely populated lowland areas. Neither the modest water volumes in new lakes nor the slow thawing of ice-rich permafrost will be able to compensate for such important deficits. Tensions may arise between water-dependent industries such as tourism, agriculture, or hydroelectricity generation because of reduced water amounts at critical times of the year (Beniston and Stoffel 2014). Solution-oriented research is increasingly needed in view of adaptation to already largely inevitable impacts.

Today, we are both retired professors but still actively involved in science-and even more concerned than in 1998 about what is going on with icy mountains in a warming world. 


\section{REFERENCES}

Beniston, M., and M. Stoffel. 2014. Assessing the impacts of climatic change on mountain water resources. Science of the Total Environment 493: 1129-1137. https://doi.org/10.1016/j. scitotenv.2013.11.122.

Beniston, M. 2015. Ratios of record high to record low temperatures in Europe exhibit sharp increases since 2000. Climatic Change 129: 225-237. https://doi.org/10.1007/s10584-015-1325-2.

Beniston, M., M. Stoffel, and S. Guillet. 2016. Comparing observed and hypothetical climates as a means of communicating to the public and policymakers: The case of European heatwaves. Environmental Science and Policy 67: 27-34. https://doi.org/10. 1016/j.envsci.2016.11.008.

Drenkhan, F., C. Huggel, L. Guardamino, and W. Haeberli. 2019. Managing risks and future options from new lakes in the deglaciating Andes of Peru: the example of the VilcanotaUrubamba basin. Science of the Total Environment 665: 465-483. https://doi.org/10.1016/j.scitotenv.2019.02.070.

Haeberli, W., and M. Beniston. 1998. Climate change and its impacts on glaciers and permafrost in the Alps. Ambio 27: 258-265.

Haeberli, W., J. Oerlemans, and M. Zemp. 2019. The future of Alpine glaciers and beyond. Oxford Research Encyclopedia, Climate Science. $\quad$ https://doi.org/10.1093/acrefore/9780190228620.013. 769.

Haeberli, W., Y. Schaub, and C. Huggel. 2017. Increasing risks related to landslides from degrading permafrost into new lakes in de-glaciating mountain ranges. Geomorphology 293: 405-417. https://doi.org/10.1016/j.geomorph.2016.02.009.

Harris, C., L.U. Arenson, H.H. Christiansen, B. Etzelmüller, R. Frauenfelder, S. Gruber, W. Haeberli, C. Hauck, et al. 2009. Permafrost and climate in Europe: Monitoring and modelling thermal, geomorphological and geotechnical responses. EarthScience Reviews 92: 117-171. https://doi.org/10.1016/j. earscirev.2008.12.002.

Hock, R., G. Rasul, C. Adler, B. Cáceres, S. Gruber, Y. Hirabayashi, M. Jackson, A. Kääb, et al. 2019. High mountain areas. In IPCC special report on the ocean and cryosphere in a changing climate, eds. H.-O. Pörtner, D.C. Roberts, V. Masson-Delmotte, P. Zhai, M. Tignor, E. Poloczanska, K. Mintenbeck, A. Alegría, et al., 131-202.

IPCC. 1997. In The Regional Impacts of Climate Change: An Assessment of Vulnerability, ed. R.T. Watson, M.C. Zinyowera, and R.H. Moss. Cambridge: Cambridge University Press.

Zemp, M., H. Frey, I. Gärtner-Roer, S.U. Nussbaumer, M. Hoelzle, F. Paul, W. Haeberli, F. Denzinger, et al. 2015. Historically unprecedented global glacier decline in the early 21 st century. Journal of Glaciology 61 (228): 745-762. https://doi.org/10. 3189/2015JoG15J017.

Publisher's Note Springer Nature remains neutral with regard to jurisdictional claims in published maps and institutional affiliations.

\section{Wilfried Haeberli $(\bowtie)$}

Address: Geography Department, University of Zurich, Winterthurerstrasse 190, 8057 Zurich, Switzerland.

e-mail: wilfried.haeberli@gmail.com

\section{Martin Beniston}

Address: Institute for Environmental Sciences, University of Geneva, Uni Carl Vogt, Bd Carl-Vogt 66, 1205 Geneva, Switzerland.

e-mail: martin.beniston@unige.ch 